\title{
No Change in Frequency of Microsatellite Instability in Colorectal Cancers over a Period of 15 or More Years
}

\author{
Peter Zauber ${ }^{1 *}$, Stephen Marotta ${ }^{2}$, Marlene Sabbath-Solitare ${ }^{2}$ \\ ${ }^{1}$ Department of Medicine, Saint Barnabas Medical Center, Livingston, NJ, USA \\ ${ }^{2}$ Department of Pathology, Saint Barnabas Medical Center, Livingston, NJ, USA \\ Email: *pzauber@barnabashealth.org, smarotta@barnabashealth.org, msabbath@barnabashealth.org
}

How to cite this paper: Zauber, P., Marotta, S. and Sabbath-Solitare, M. (2017) No Change in Frequency of Microsatellite Instability in Colorectal Cancers over a Period of 15 or More Years. Open Journal of Gastroenterology, 7, 45-51.

https://doi.org/10.4236/ojgas.2017.72006

Received: October 25, 2016

Accepted: February 5, 2017

Published: February 8, 2017

Copyright $\odot 2017$ by authors and Scientific Research Publishing Inc. This work is licensed under the Creative Commons Attribution International License (CC BY 4.0). http://creativecommons.org/licenses/by/4.0/

\begin{abstract}
Microsatellite instability (MSI) is a molecular change resulting from inactivation of DNA mismatch repair systems, occurring with a reported incidence between $15 \%-20 \%$ of all sporadic colorectal cancers. Our aim was to determine whether a change in the incidence of MSI in colorectal cancer had occurred at our institution over time. We assayed 106 cases from the mid-1990s and 69 cases from 15 or more years later for MSI. Those tumors with MSI were assayed for $B R A F$ mutation and methylation. MSI was detected in 15 (14.2\%) of the early cases and 11 (15.9\%) of the later cases. For the two groups with MSI, a similar percentage was methylated and had a BRAF mutation. One tumor in each group was MSI, unmethylated, and $B R A F$ wild type. Our data indicate consistency in the frequency of microsatellite unstable colorectal cancer across a time span of 15 or more years.
\end{abstract}

\section{Keywords}

Colorectal Cancer, Microsatellite Instability, BRAF Mutation,

DNA Methylation

\section{Introduction}

Microsatellite instability (MSI) is a mutational change resulting from inactivation of DNA mismatch repair systems, first reported in colorectal cancers in the early 1990s [1]. When DNA repair is defective, microsatellites, which are repetitive nucleotide sequences, may become either shorter or longer in length, as compared with normal tissue DNA from the same individual. Mismatch repair may be defective because of a germ line mutation in one of several genes responsible for the repair system. These germ line mutations account for approximately 
$2 \%$ of all colorectal cancers [2] and for approximately $12 \%$ of all colorectal cancers that are MSI [3]. However, the majority of colorectal cancers demonstrating MSI are the result of an acquired loss of DNA repair function, usually resulting from methylation of the promoter region of a repair gene, frequently the gene $M L H I[4]$.

Most reports have indicated an incidence of MSI between 15\% - 20\% of sporadic colon cancers [5]. However, a reported incidence may partly reflect demographics, such as age of the studied population. Furthermore, exogenous factors may influence the incidence of MSI. For example, cigarette smoking has been associated with microsatellite instability in sporadic colon cancer [6]. Additionally, over the past several decades, investigators have used different microsatellite markers, which may result in discrepant findings. We were interested in determining whether a change in the incidence of MSI in colorectal cancer had occurred at our institution over time. To address this question, we assayed cases from the mid-1990s and from 15 or more years later-during the late-2000sfor microsatellite instability, using the same microsatellites and the same laboratory procedure. In addition, we assayed those tumors with MSI for $B R A F$ mutation and for methylation.

\section{Materials and Methods}

We previously retrospectively identified all 122 patients with Dukes' Stage B colorectal cancer treated at our hospital with primary surgery between 1993-1996. These cases had been collected in 2000 for an independent study by the pathology department, and the results were reported in 2004. No clinical information was available regarding these patients [7]. From 2006 to 2011, we prospectively enrolled 69 patients of three cooperating colorectal surgeons specifically for a study to evaluate their colorectal cancers for MSI. All patients who were at home one month after surgery were offered participation. Written consents were obtained from all patients in this group. The studies were approved by the hospital Institutional Review Board, with a waiver to study the early pathological material. Clinical material primarily reflected a stable suburban community of middle economic level. The majority of patients were Caucasians. One clinical pathologist reviewed all histological slides to indicate the areas for study.

\subsection{DNA Extraction and Purification}

All tissue specimens were formalin-fixed and paraffin-embedded. DNA was isolated and purified using the QIAamp DNA Mini Kit (Qiagen Inc., Valencia, CA).

Microsatellite analysis for MSI was performed using the Bethesda panel of markers that includes two mononucleotide markers BAT25 and BAT26, and three dinucleotide markers D2S123, D5S346, and D17S250. Microsatellite primer sets were ordered through the Life Technologies Custom Oligo Synthesis Service (genomicorders@lifetech.com). Reactions were run on an ABI 9700 thermal cycler (Applied Biosystems, Foster City, CA) as previously described [8]. A 
tumor was defined as MSI-high if two or more of the five markers had a changed allele pattern. The codon 600 region in exon 15 of the BRAF gene was amplified using the primer set 5'CATAATGCTTGCTCTGATAGGAAA-3' sense and 5'-GATCCAGACAACTGTTCAAACTG-3'. The methylation status of the mismatch repair (MMR) system was ascertained using the SALSA ${ }^{\star}$ MS-MLPA ${ }^{\star}$ Methylation-specific DNA detection Kit \#ME011-B1 (MRC-Holland, Amsterdam, Netherlands) [9].

\subsection{Statistical Methods}

The $t$-test was used to assess for difference in age at diagnosis for the two groups. The Mantel-Haenszel chi-square test was used to compare the percentage with mutation between the two groups with control for age at diagnosis of less than 70 and 70 or older and to assess whether there was heterogeneity in the difference by age group.

\section{Results}

The early cases were all from 1993-1996. Additional analyses were performed on 106 of the original 122 samples, as paraffin blocks were not available, or did not yield adequate DNA, for 16 patients. Between 2006 and 2011 our Pathology Department processed 217 cases of colorectal cancer under the care of participating surgeons, who contacted the patients regarding interest in the study. Although $123(56.7 \%)$ patients expressed willingness to participate, only $69(31.8 \%)$ returned the consent form and participated in a telephone interview.

The early and late time period groups contained a similar percentage of males and females. The mean age of diagnosis for the early group is greater than the mean age for the later group (Table 1). The age range for the early time period is from 48 to 95 years, and for the later time period it is from 42 to 91 years. The distribution between right and left sided location of the cancers was similar for both groups. The majority of the cancers during the later time period were Stage 2 and 3 (Table 1 ).

\subsection{Early Cases}

Among the 106 early cases, 15 (14.2\%) demonstrated MSI. Of these fifteen, 14 demonstrated $M L H 1$ methylation, 9 with a $B R A F$ mutation at codon 600, and 5 demonstrated wild-type $B R A F$ (Table 2). Among the five tumors with methylation but $B R A F$ wild, two showed limited methylation of $M L H 1$, but demonstrated strong methylation for $M G M T$. One of the 15 MSI cancers was unmethylated and $B R A F$ wild-type. This patient was 58 years old at the time of his cancer surgery.

\subsection{Later Cases}

Among the 69 later cases, 11 (15.9\%) demonstrated MSI, of which 10 were methylated (Table 2). Six of these 10 tumors all demonstrated $M L H 1$ methylation and BRAF mutation. Four of these 10 tumors demonstrated wild type BRAF; two demonstrated limited, and one demonstrated absent methylation of $M L H 1$, 
Table 1. Clinical characteristics of patients and their cancers from two time periods.

\begin{tabular}{lccc}
\hline & Early Cases & Late Cases & p-value \\
\cline { 2 - 3 } & No. (\%) & No. $(\%)$ & \\
Total & 106 & 69 & 0.61 \\
Female & $62(58.5)$ & $43(62.3)$ & \\
Male & $44(41.5)$ & $26(37.7)$ & 0.73 \\
Age +/- S.E. & $70.4(1.29)$ & $64.2(1.51)$ & \\
Left side & $51(48.1)$ & $34(49.3)$ & \\
Stage & $55(51.9)$ & $35(50.7)$ & \\
0 & & $1(1.5)$ & \\
1 & 0 & $21(30.4)$ & \\
2 & 0 & $24(34.8)$ & \\
3 & 0 & $16(23.2)$ & \\
4 & $106(100)$ & $7(10.1)$ & \\
\hline
\end{tabular}

Table 2. Molecular changes in colorectal cancers from two time periods.

\begin{tabular}{cccc}
\hline Group & Early cases & Late cases & p-value \\
\hline Time period: & $1993-1996$ & $2006-2011$ & \\
\# Cancers & 106 & 69 & \\
MSS & $91(85.8)$ & $58(84.1)$ & 0.40 \\
MSI-high & $15(14.2)$ & $11(15.9)$ & \\
Methylated & $14(93.3 \%)$ & $10(90.9 \%)$ & \\
Methylated and $B R A F^{*}$ mutated & $9(64.3 \%)$ & $6(60 \%)$ & \\
Methylated and $B R A F$ wild & $5(35.7 \%)$ & $4(40 \%)$ & \\
Unmethylated and $B R A F$ wild & $1(6.7 \%)$ & $1(9.1 \%)$ & \\
\hline
\end{tabular}

${ }^{\star}$ Gene for serine/threonine-protein kinase B-Raf (Rapidly Accelerated Fibrosarcoma).

but all three showed strong MGMT methylation. One of the 11 cancers with MSI was unmethylated and $B R A F$ wild. This patient was 60 years old at the time of his surgery (Table 2).

Family history was available for 68 of the 69 patients in this later group. We have analyzed their histories with consideration for those tumors found in Lynch syndrome: colon, uterus, ovary, stomach, small bowel, pancreas, bladder, kidney, and bile ducts. Seventeen patients reported no cancers in any of their first-degree relatives. Twenty-two patients reported non-Lynch associated cancers in first-degree relatives; 16 had only one relative with a non-Lynch associated cancer, 4 had two relatives, and 2 had three such first-degree relatives. 
Twenty-nine patients reported Lynch-associated cancers in one or more firstdegree relatives. Sixteen patients had just one first-degree relative, 8 had two first-degree relatives, 3 had three first-degree relatives, and 2 had four-first degree relatives with a Lynch-associated cancer. Limiting the analysis to first-degree relatives with a Lynch-associated cancer diagnosed before the age of 50 years, however, reveals five patients with one first-degree relative with a Lynch-associated cancer, one patient with two first-degree relatives with a Lynch-associated cancer, and just one patient with three first-degree relatives with Lynch-associated cancers. This patient's tumor was MSI, but lacked methylation and was $B R A F$-wild.

\section{Discussion}

Within both of our groups, there were more females than males. The female to male ratio was similar for those patients who were contacted but did not participate and for the patients with missing blocks from the early group (data not shown). This is not the usual reported gender ratio; however, competing sources of care in our geographic area could be part of the explanation, with more men than women seeking surgery elsewhere, once a diagnosis was established. The mean age of diagnosis for the early group is older than the mean age for the later group, perhaps reflecting more pervasive colorectal screening during the later time period, resulting in the detection of cancers at an earlier age.

Several limitations should be noted. Prospective accrual for the later cases was poor, reflecting the general difficulty of patient accrual to clinical studies. The early group patients were all Stage 3, while the later group represented all stages, but primarily Stages 1 - 3. Previous studies have shown a similar incidence of MSI in these stages [10] [11]. One strength of our study is the use of the same microsatellite markers and techniques in studying cases from both time periods. Both groups contained only one individual with molecular findings suggesting a germ line cause for their tumors' microsatellite instability. Despite more public awareness of familial colorectal cancer, we have not observed any increase in frequency of this subgroup.

Cigarette use in our area has decreased from approximately $21 \%$ of the adult population during our initial time interval, to approximately $16 \%$ in the later time period. This trend reflects overall U.S. rates [12]. The stability in the incidence of microsatellite unstable colorectal cancer despite the fall in smoking suggests possibly a longer lag-time for the molecular genetics effects of smoking.

\section{Conclusion}

In conclusion, our data indicate consistency in the frequency of microsatellite unstable colorectal cancer across a time span of 15 or more years, despite an average age of diagnosis that is younger in the more recent group, and despite a falling prevalence of cigarette use within the general community.

\section{Acknowledgements}

Thanks to Dr. Errol Berman for review of histological slides. 


\section{Declaration of Competing Interests}

All authors indicate no competing interests.

\section{Funding Sources}

H. Nussbaum Foundation of Saint Barnabas Medical Center and the June Bleiwise Foundation.

\section{References}

[1] Thibodeau, S.N. and Schaid, B.G. (1993) Microsatellite Instability in Cancer of the Proximal Colon. Science, 260, 816-819. https://doi.org/10.1126/science.8484122

[2] Cunningham, J.M., Kim, C.Y., Christensen, E.R., Tester, D.J., Parc, Y., Burgart, L.J., Halling, K.C., McDonnell, S.K., Schaid, D.J., Walsh Vockley, C., Kubly, V., Nelson, H., Michels, V.V. and Thibodeau, S.N. (2001) The Frequency of Hereditary Defective Mismatch Repair in Prospective Series of Unselected Colorectal Carcinomas. The American Journal of Human Genetics, 69, 780-790. https://doi.org/10.1086/323658

[3] Poynter, J.N., Siegmund, K.D., Weisenberger, D.J., Long, T.I., Thibodeau, S.N., Lindor, N., Young, J., Jenkins, M.A., Hopper, J.L., Baron, J.A., Buchanan, D., Casey, G., Levine, A.J., Le Marchand, L., Gallinger, S., Bapat, B., Potter, J.D., Newcomb, P.A., Haile, R.W., Laird, P.W. and Colon Cancer Family Registry Investigators (2008) Molecular Characterization of MSI-H Colorectal Cancer by MLH1 Promoter Methylation, Immunohistochemistry, and Mismatch Repair Germline Mutation Screening. Cancer Epidemiology, Biomarkers \& Prevention, 17, 3208-3215. https://doi.org/10.1158/1055-9965.EPI-08-0512

[4] Miyakura, Y., Sugano, K., Konishi, F., Ichikawa, A., Maekawa, M., Shitoh, K., Igarashi, S., Kotake, K., Koyama, Y. and Nagai, H. (2001) Extensive Methylation of hMLH1 Promoter Region Predominates in Proximal Colon Cancer with Microsatellite Instability. Gastroenterology, 121, 1300-1309. https://doi.org/10.1053/gast.2001.29616

[5] Burgart, L.J. (2005) Testing for Defective DNA Mismatch Repair in Colorectal Carcinoma. Archives of Pathology \& Laboratory Medicine, 129, 1385-1389.

[6] Slattery, M.L., Curtin, K., Anderson, K., Ma, K.N., Ballard, L., Edwards, S., Schaffer, D., Potter, J., Leppert, M. and Samowitz, W.S. (2000) Associations between Cigarette Smoking, Lifestyle Factors, and Microsatellite Instability in Colon Tumors. Journal of the National Cancer Institute, 92, 1831-1835. https://doi.org/10.1093/jnci/92.22.1831

[7] Zauber, N.P., Wang, C., Lee, P.S., Redondo, T., Bishop, D.T. and Goel, A. (2004) Ki-Ras Gene Mutations, LOH of the APC and DCC Genes, and Microsatellite Instability in Primary Colorectal Carcinoma Are Not Associated with Micrometastases in Pericolonic Lymph Nodes or with Patients' Survival. Journal of Clinical Pathology, 57, 938-942. https://doi.org/10.1136/jcp.2004.017814

[8] Zauber, N.P., Berman, E., Marotta, S., Sabbath-Solitare, M. and Bishop, T. (2011) Ki-Ras Gene Mutations Are Invariably Present in Low-Grade Mucinous Tumors of the Vermiform Appendix. Scandinavian Journal of Gastroenterology, 46, 869-874. https://doi.org/10.3109/00365521.2011.565070

[9] Zauber, P., Huang, J., Sabbath-Solitare, M. and Marotta, S. (2013) Similarities of Molecular Genetic Changes in Synchronous and Metachronous Colorectal Cancers Are Limited and Related to the Cancers' Proximities to Each Other. Journal of Molecular Diagnostics, 15, 652-660. https://doi.org/10.1016/j.jmoldx.2013.03.009 
[10] Ward, R.L., Cheong, K., Ku, S.L., Meagher, A., O'Connor, T. and Hawkins, N.J. (2003) Adverse Prognostic Effect of Methylation in Colorectal Cancer Is Reversed by Microsatellite Instability. Journal of Clinical Oncology, 21, 3729-3736. https://doi.org/10.1200/JCO.2003.03.123

[11] Samowitz, W.S., Sweeney, C., Herrick, J., Albertsen, H., Levin, T.R., Murtaugh, M.A., Wolff, R.K. and Slattery, M.L. (2005) Poor Survival Associated with the BRAF V600E Mutation in Microsatellite-Stable Colon Cancers. Cancer Research, 65, 6063-6069. https://doi.org/10.1158/0008-5472.CAN-05-0404

[12] National Health Interview Survey, 1965-2011. Office on Smoking and Health, National Centers for Chronic Disease Prevention and Health Promotion. www.cdc.gov/tobacco/data_statistics/tables/trends/cig_smoking/index.htm

Submit or recommend next manuscript to SCIRP and we will provide best service for you:

Accepting pre-submission inquiries through Email, Facebook, LinkedIn, Twitter, etc. A wide selection of journals (inclusive of 9 subjects, more than 200 journals)

Providing 24-hour high-quality service

User-friendly online submission system

Fair and swift peer-review system

Efficient typesetting and proofreading procedure

Display of the result of downloads and visits, as well as the number of cited articles Maximum dissemination of your research work

Submit your manuscript at: http://papersubmission.scirp.org/

Or contact ojgas@scirp.org 